\title{
CONCERNING EXPERIENCE AND PROSPECTS OF DEVELOPMENT OF BIOGAS POWER ENGINEERING IN ONE OF RUSSIA'S ENERGY-DEFICIENCY AGRICULTURAL REGIONS
}

\author{
Vera Samarina ${ }^{1}$, Tatiana Skufina ${ }^{2}$, Aleksandr Samarin ${ }^{3}$, Maria Tereshina ${ }^{4}$ \\ ${ }^{1}$ Staryy Oskol Technological Institute, branch of National Research Technological \\ University "MISIS", Russia; ${ }^{2}$ Federal Research Centre Kola Science Centre \\ of the Russian Academy of Sciences, Institute of Economic Problems, Russia; \\ ${ }^{3}$ Belgorod State National Research University \\ (Staryy Oskol Branch), Russia; ${ }^{4}$ Kuban State University, Russia \\ samarina_vp@mail.ru, skufina@gmail.com, alvic_samarin@mail.ru, mwstepanova@mail.ru
}

\begin{abstract}
The experience of use of technologies for biogas generation of heat and electric energy in the Russia's energy-deficient agricultural region has been presented in the paper. Based on the resource base analysis, the possibilities of expanding the use of biogas power engineering technologies have been revealed. The object of the research was the Belgorod region, recognized as one of the most energy-deficient Russia's regions. At the same time, the industry in the Belgorod region is developed. The research has shown that the Belgorod region has achieved significant success in the development and application of bioenergy technologies. The paper shows that in addition to generating heat and electricity, biogas energy solves one of the vital problems of the Belgorod region - the processing of agricultural waste. The infrastructure that has existed in the region contributes to structural improvement in energy generation towards bioenergy. Bioenergy is an actor in the creation of innovative products and scientific and technological achievements for various areas of the agricultural sector. This leads to the appearance of positive effects of the development of the Belgorod region's agricultural environment.
\end{abstract}

Keywords: thermal energy, electrical energy, alternative energy generation, biogas energy, methane fermentation, energy-deficient region, agricultural region.

\section{Introduction}

In the modern economy, energy is one of the main regional resources that ensure vital activity of the population and production development. One can distinguish traditional and alternative sources of thermal and electrical energy $[1 ; 2]$. The development of the alternative energy makes a significant impact on the condition of territorial communities, first of all, due to the increase in the environmental component of life quality [3; 4]. It is especially important for agricultural areas with energy shortages and resource specialization. In turn, high degree of locality and specificity of functioning of the agricultural complexes that have developed in Russia requires unfailing supply of heat and energy resources [5; 6].

Biogas energy (or bioenergy) is a type of alternative energy which is based on biogas production that is mixture of fire gases, predominately methane. Biogas is formed as a result of an anaerobic microbiological process from organic substances $[7 ; 8]$. The decomposition of biomass is differently called methane fermentation [9].

The current stage of the green economy development involves some structural improvement towards bioenergy as a direct actor in the creation of innovative products and scientific and technological achievements for an agro industrial complex [10-12].

The purpose of the research is to study experience and reveal opportunities for expanding the use of biogas energy technologies in one of Russia's energy-deficient agricultural regions - the Belgorod region.

To achieve the goal it is necessary to solve the following problems:

1. To assess the sufficiency of electricity to ensure the vital activity of the population and production needs of the Belgorod region.

2. To reveal industrial, economic and environmental problems of using traditional sources of thermal and electric energy in the Belgorod region.

3. To assess the resources of biogas energy in the Belgorod region.

4. To study the experience and possibilities of bioenergy technologies using in the Belgorod region. 


\section{Materials and methods}

The object of the research was energy sources of the Belgorod region - the subject of the Russian Federation. The Belgorod region is located in the south-west of Russia, in the temperate zone. In this region long-term industrial production is combined with intensive agricultural activity. The guidelines of production are mining and processing of iron ore and agriculture.

The Belgorod region is considered as one of the most energy-deficient regions in Russia. At the same time, industry in the Belgorod region is developed. The main consumer of electricity is the Oskol Electrometallurgical Plant and other industrial enterprises. The needs of agricultural enterprises, due to the characteristics of their technological processes, are less. However, on the one hand, agricultural production which at present is developed requires more and more electric energy; on the other hand, the activity of the regional agricultural complex leads to the accumulation of organic waste [13].

In order to reveal the possibility of expanding the use of biogas energy technologies, the systematic approach is used. Within the framework of this approach the Belgorod region is considered as a system, and energy generation as an integral segment of this system. In contrast to existing traditions stressing on the study of traditional sources of thermal and electric energy, the subject of the research is alternative biogas power engineering.

The information and analytical base of the research is made up of the data published on the website of the Belgorod Region's Government; the materials from the Belgorod Energy Retail Company, which distributes regional energy resources; the materials of AltEnergo LLC, which introduce alternative energy projects; information presented in periodicals and monographs of Russian and foreign authors and the results of the authors' research as well.

\section{Results and discussion}

\section{Electricity sufficiency assessment for the needs of the Belgorod region}

To assess the sufficiency of electric power for industrial needs, we present the ratio of electricity consumption and electric power generation in the Belgorod region in Table 1.

Table 1

Ratio of electricity consumption and electric power generation in the Belgorod Region (according to the data of Belgorod Energy Retail Company)

\begin{tabular}{|c|c|c|c|c|c|c|}
\hline \multirow[b]{2}{*}{ Indicator } & \multicolumn{2}{|c|}{2017} & \multicolumn{2}{|c|}{2018} & \multicolumn{2}{|c|}{ Growth } \\
\hline & $\begin{array}{l}\text { mln. } \\
\text { kWh }\end{array}$ & $\begin{array}{c}\text { Share, } \\
\%\end{array}$ & $\begin{array}{l}\text { mln. } \\
\text { kWh }\end{array}$ & $\begin{array}{c}\text { Share, } \\
\%\end{array}$ & $\begin{array}{l}\text { mln. } \\
\text { kWh }\end{array}$ & $\begin{array}{c}\text { Share, } \\
\%\end{array}$ \\
\hline Electricity consumption & 14881 & 100 & 15216 & 100 & 335 & 0 \\
\hline Electric power generation & 714 & 4.80 & 598 & 3.93 & -116 & -0.87 \\
\hline $\begin{array}{l}\text { Balance of energy flow to the } \\
\text { energy system }\end{array}$ & 14167 & 95.20 & 14618 & 96.07 & 451 & 0.87 \\
\hline
\end{tabular}

We should note acute shortage of electric power in the Belgorod region. Its own sources provide less than $5 \%$ of the required electricity. At the same time, energy consumption is growing, and electricity generation is falling.

Thermal power plants are electric power generators. Main body of electric power is produced by combined heat and power plants. They not only produce the energy necessary for the region, but are a source of thermal energy in centralized heat supply systems as well. Steam and hot water are used in hot water supply and heating systems of residential communities and industrial projects [14]. Producible capacities of thermal power stations (TPS) of the Belgorod region are presented in Table 2.

Belgorod TPS was built in 1938 according to the GOELRO plan and first was coal-fired; since 1958 the TPS has used natural gas and heavy oil has been used as reserve fuel. In 2007 a gas turbine power station was installed at the Belgorod TPS site. Gubkinskaya TPS was built, first of all, for the needs of the metallurgical plant "KMARuda". Gubkinskaya TPS operates on natural gas, coal is used as reserve fuel. Before the construction of the TPS in 1952, three power trains provided power-supply. Gas turbine TPSs are the most modern large facilities of traditional energy production in the Belgorod region. They operate on natural gas. The Michurinskaya gas turbine TPS was launched in 2004, and 
the gas turbine TPS Luch in 2005. The principle of the operation of the Luch and Michurinskaya gas turbine power plants is based on the production of electricity in a gas turbine plant and heat in a waste heat boiler. Electric power is sold in the wholesale market, and heat is used for Belgorod needs.

Table 2

Producible capacities of thermal power stations (TPS) of the Belgorod region (according to the data of Belgorod Energy Retail Company)

\begin{tabular}{|l|c|c|}
\hline \multicolumn{1}{|c|}{ Indicator } & Thermal power, Gcal $\cdot$ hour $^{-1}$ & Electric power, $\mathbf{M W}$ \\
\hline Belgorod TPS & 300 & 60 \\
\hline Gubkinskaya TPS & 148 & 29 \\
\hline Belgorod gas turbine TPS & 60 & 60 \\
\hline Gas turbine TPS Michurinskaya & 80 & 36 \\
\hline Gas turbine TPS Lutch & 62 & 60 \\
\hline
\end{tabular}

\section{Problems of traditional sources of thermal and electric energy use in the Belgorod region}

The use of thermal power plants as sources of electricity in the Belgorod region leads to the accumulation of production, economic and environmental problems.

Production problems are related to the fact that the equipment of TPSs and power grids are physically and mentally outdated. This first of all refers to the Belgorod and Gubkinskaya TPSs, which were installed in the Soviet Union more than 65 years ago. Physical depreciation leads to frequent breakdowns and additional maintenance and repair expenses. Moral depreciation leads to the fact that the equipment has a low coefficient of efficiency.

Economic problems closely related to the production ones are the high cost price of energy generation. The Belgorod region does not have its own traditional energy resources. Natural gas, heavy oil, coal used as fuel are delivered from other Russia's regions. Thermal power plants are very dependent on resource suppliers who constantly raise prices. This fact combined with maintenance and repair costs of obsolete equipment, leads to a high cost of electricity production. As a result, selling price of energy is growing all the time.

We should especially note the environmental factor in the use of thermal power plants as sources of electric power in the Belgorod region. Natural energy resources used in the operation of thermal power stations are non-renewable. Their reserves are finite, the deposits peter out [15; 16]. In addition, TPSs are main suppliers of pollutants and excessive heat to the atmosphere [17]. Our research has shown that the landscape of the territory and the wind rose lead to the fact that the combustion products are transported to considerable distances, polluting natural environment [13].

Thus, currently the following conditions have developed in the Belgorod region:

- increasing energy consumption, including by agricultural production;

- very large shortage of electricity of domestic production;

- severe dependence on external energy suppliers;

- limited and high cost of traditional fuel resources;

- negative impact of thermal power plants on the natural environment.

This generates a need for taking the question of searching for electrical energy reserves seriously. As said at the World Energy Congress 2019, one of the lines is energy saving and application of power efficient technologies at enterprises, including agricultural enterprises [18]. The use of alternative, local renewable energy sources is a promising trend. Our research has shown that there are prospects for solar and wind energy in the Belgorod region [4]. The total volume of green energy production is more than 20 million kWh of electric and 17.2 thousand Gcal of thermal energy per year.

\section{Prospects of biogas power engineering in the Belgorod region}

Biogas with higher calorific power is formed as a result of anaerobic methane fermentation from biomass, which is an organic waste of the region's agro-industrial complex [19; 20]. As a result, in addition to receiving heat and electric energy, biogas energy solves one of the urgent problems of the Belgorod region - the processing of agricultural waste. 
The total annual volume of animal and poultry waste in the Belgorod region exceeds 18 million tons. Burial of agricultural waste cannot bring profit. Our research has shown that no more than $15 \%$ of manure is used as fertilizer. The rest of the waste is accumulating. Also, a large amount of waste is given by crop production. We propose to make greater use of the capabilities of biogas stations, which allow not only to get rid of waste, but also to extract the maximum benefit from them. The energy potential of biogeneration facilities is presented in Table 3. Our research has shown that no more than $15 \%$ of the fertilizer is used as fertilizer.

Table 3

Energy potential of bio-generation facilities in the Belgorod Region (the authors' calculations based on the materials from AlEnergo LLC)

\begin{tabular}{|c|c|c|c|c|c|c|}
\hline \multirow{2}{*}{$\begin{array}{l}\text { Energy } \\
\text { potential }\end{array}$} & Power & Electricity & $\begin{array}{c}\text { Thermal } \\
\text { energy }\end{array}$ & $\begin{array}{l}\text { Fertilizer } \\
\text { production }\end{array}$ & $\begin{array}{c}\text { Greenhouse } \\
\text { gas reduction }\end{array}$ & $\begin{array}{l}\text { Ability to provide } \\
\text { population with } \\
\text { electricity }\end{array}$ \\
\hline & MW & $\begin{array}{c}\text { million } \\
\mathrm{kWh} \cdot \text { year }^{-1}\end{array}$ & $\begin{array}{l}\text { thousand } \\
{\text { Gcal } \cdot \text { year }^{-1}}\end{array}$ & $\begin{array}{l}\text { thousand } \\
\text { tons. }^{-} \text {year }^{-1}\end{array}$ & $\begin{array}{c}\mathrm{mln} \\
\text { tons }^{\text {year }}{ }^{-1}\end{array}$ & $\begin{array}{c}\text { thousand } \\
\text { people } \cdot \text { year }^{-1}\end{array}$ \\
\hline Total & 223 & 1766 & 1693 & 7362 & 1324 & 1124 \\
\hline Pig waste & 77 & 605 & 580 & 2524 & 454 & 385 \\
\hline Cattle waste & 46 & 363 & 348 & 1511 & 272 & 231 \\
\hline Poultry waste & 39 & 306 & 294 & 1273 & 230 & 194 \\
\hline Plant crop waste & 27 & 212 & 203 & 885 & 160 & 134 \\
\hline $\begin{array}{c}\text { Treatment plants } \\
\text { waste and solid } \\
\text { domestic waste }\end{array}$ & 26 & 207 & 198 & 864 & 155 & 132 \\
\hline Industrial waste & 9 & 73 & 70 & 305 & 54 & 48 \\
\hline
\end{tabular}

The reduced data show the sufficient resource potential for the development of bioenergy.

Fertilizers produced by biogas stations deserve special attention. Bioreactors (fermenters) that process organic waste can produce highly effective biofertilizers - effluent. Effluent has significant advantages over other organic fertilizers (manure, litter, peat). The main ones are:

- is well assimilated by crops;

- does not contain pathogenic bacteria;

- excellent accumulation of nitrogen, phosphorus and other nutrients needed by plants;

- retains nutrients for a long time;

- contributes to the humification of the soil [21].

Bioenergy is an actor in the creation of innovative products and scientific and technological achievements for various areas of the agricultural sector $[22 ; 23]$. This leads to the appearance of positive effects of the development of the Belgorod region's agricultural environment. It is shown in Figure 1.

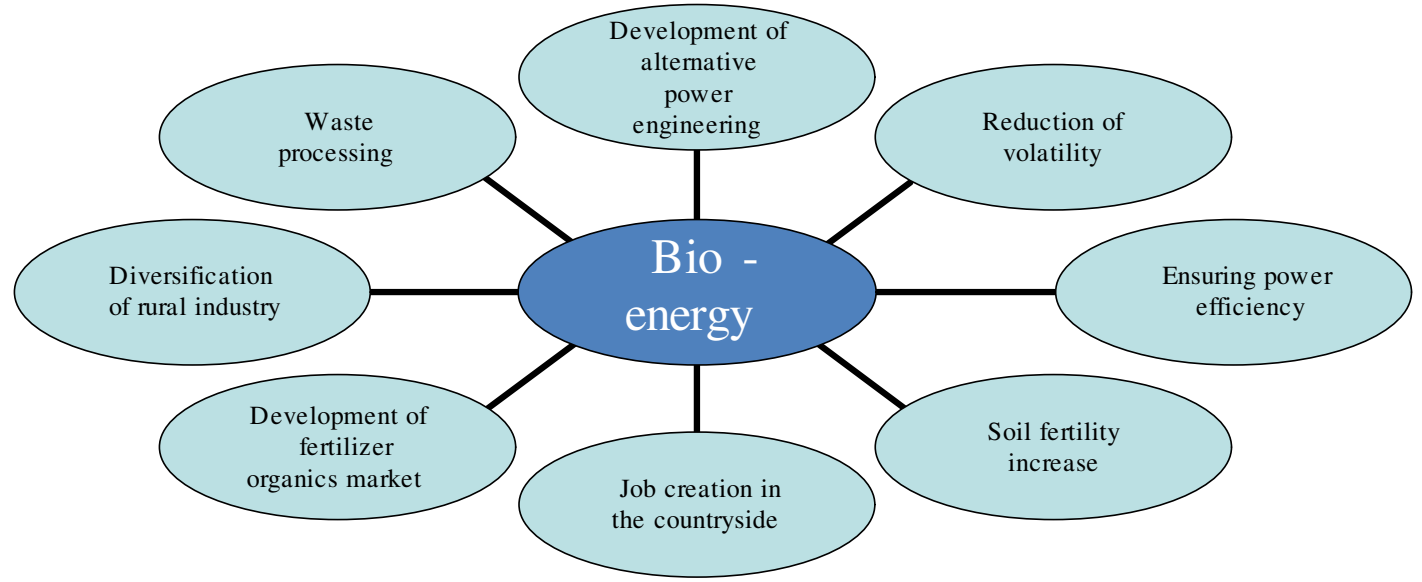

Fig. 1. Positive effects from development of bioenergy (developed by the authors) 
Thus, bioenergy contributes to the comprehensive development of the Belgorod region's agricultural environment.

\section{Experience and possibilities of bioenergy technologies use in the Belgorod region}

In mid-2012, Russia's first industrial-scale biogas plant Luchki was built in the Prokhorovsky District of the Belgorod Region. It operates on the waste of the Agro-Belogorye meat processing plant and other nearby agricultural enterprises developing at an accelerated pace in the region [12]. For a year, a biogas plant generates on average about 20 million $\mathrm{kW} \cdot \mathrm{h}$ of electric energy, 18 thousand Gcal of thermal energy and about 70 thousand $\mathrm{m}^{3}$ of organic biofertilizers. According to the official data of AltEnergo, for 8 months of 2017, the biogas station generated 15.6 million kWh of electric energy. At the same time, more than 40 thousand tons of waste were processed, of which about 27 thousand tons were livestock waste [13]. A biogas station based on the Strigunovsky pig complex operates in the Borisov district of the Belgorod region. These objects have become the base for the whole network of biogas stations in the Belgorod region. Since the launch of the biogas energy project, a total of about 350 thousand tons of crop and livestock wastes have been converted into "green" energy.

The "Luchki" biogas station annually produces 66.8 thousand $\mathrm{m}^{3}$ of effluent biofertilizer. The experiment, which was conducted in the agricultural laboratory, showed a high efficiency of effluent. The study was carried out on experimental sites, in the soil of which biofertilizer was added, and at control sites, in the soil of which biofertilizer was not added. The addition of $90 \mathrm{~m}^{3}$ effluent per hectare of arable land on the pilot site resulted in a 4.5 centner increase in maize yields compared to the control site. The addition of $80 \mathrm{~m}^{3}$ effluent per hectare of arable land on the pilot site resulted in an increase in soybean yields of 4.13 centners compared to the control site.

Bioenergy technologies have shown their high efficiency in the Belgorod region. Agricultural production can provide biogeneration facilities with resources in abundance. Therefore, in the future, biogas plants can be built up in great quantities, as is shown in Figure 2.

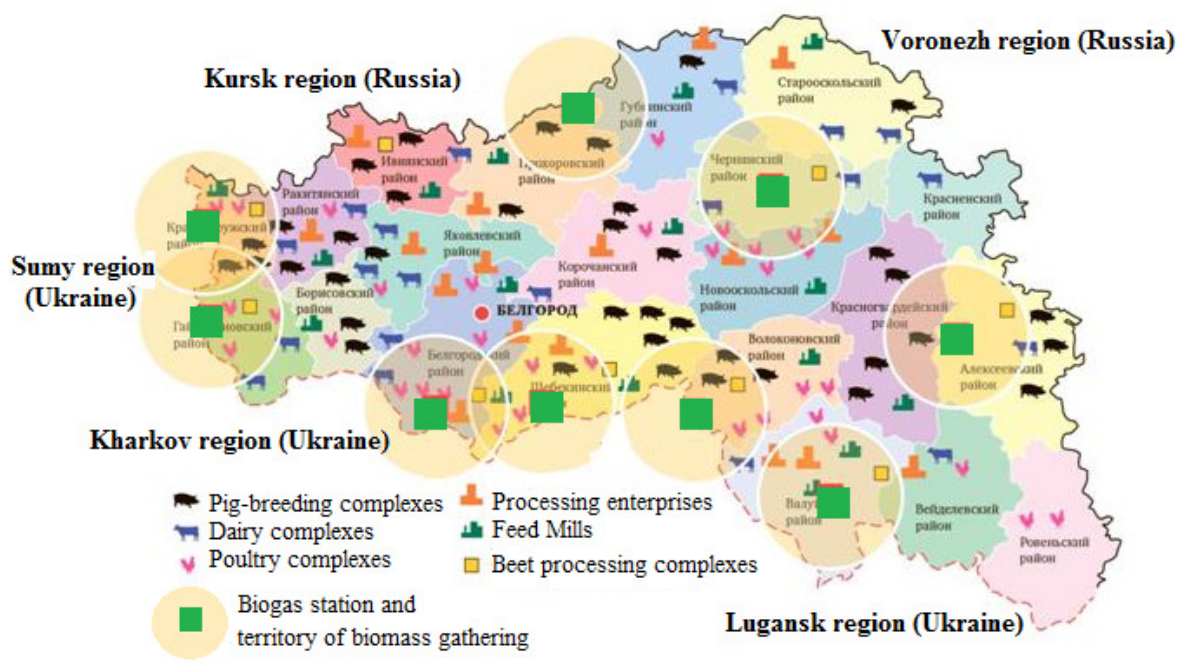

Fig. 2. The suggested location of biogas stations in the Belgorod region (developed by the authors based on the materials from AlEnergo LLC)

The location of biogas stations was based on the availability of production resources (livestock breeding complexes biological waste), labour resources (inhabitants of rural areas, infrastructure (availability of roads and communication facilities), as well as landscape conditions (flat terrain suitable for station location and other necessary premises).

It is noticeable that projects of biogas plant construction are often realized at the expense of public-private partnerships. The volume of investments placed by regional authorities in each biogas station is about 150 million RUR. Such sharing of financial burden and entrepreneurial risks contributes to the increase of financial strength of bioenergy projects in the agro-industrial complex of the Belgorod region [14]. 
However, it should be taken into account that modern bioenergy technologies are not able to meet the needs of industry and the population of the Belgorod region in electricity and heat. The production of thermal and electric energy using the methane fermentation technology must be combined in a comprehensive manner with other, traditional energy generation technologies. Such an approach will contribute to rapid development of agriculture in the region and other sectors of economic activity.

\section{Conclusions}

1. Having summarized the data obtained, it can be concluded that the Belgorod region is an energydeficient region and its own sources provide less than $5 \%$ of the required electrical energy. Power consumption is growing and power generation is slumping.

2. Heat and power plants supplying the Belgorod Region with heat and electric energy generate such significant problems as: lack of energy for the regional needs, high cost of energy for consumers and negative impact on the environment.

3. The Belgorod region has achieved significant success in the development and application of bioenergy technologies. The infrastructure that has developed in the region contributes to structural improvement in energy generation towards bioenergy. Bioenergetics acts as a direct actor in the creation of innovative products and scientific and technological achievements for agricultural production. This leads to the appearance of positive effects of the development of the Belgorod region's agricultural environment.

4. Bioenergy technologies have shown their high efficiency in the Belgorod region. Agricultural production can provide biogeneration facilities with resources in abundance. Therefore, in the future, biogas plants can be built up in great quantities. The biogeneration of thermal and electric energy must be combined in a comprehensive manner with other, traditional energy generation technologies. Such an approach will contribute to rapid development of agriculture in the region and other sectors of economic activity.

\section{References}

[1] Epstein A. The Moral Case for Fossil Fuels. New York, Portfolio/Penguin, 2012.

[2] Samarina V.P., Skufina T.P. and Baranov S.V. Comparative estimation of power efficiency of countries and world regions. Actual Problems of Economics, vol. 11 (173), 2015. pp. 127-136.

[3] Sachs J. and Warner A. The curse of natural resources. European Economic Review, vol. 45, 2001, pp. 128-132.

[4] Samarina V., Skufina T., Samarin A. and Ushakov D. Alternative Energy Sources: Opportunities, Experience and Prospects of the Russian Regions in the Context of Global Trends. International Journal of Energy Economics and Policy, vol. 8(2), 2018, pp. 140-147.

[5] Johnson J.A., Runge C.F., Senauer B., Foley J. and Polasky S. Global agriculture and carbon trade-offs. Proceedings of the National Academy of Sciences, vol. 111 (34), 2014, pp. 12342 12347.

[6] Samarina V.P., Skufina T.P., Samarin A.V. and Baranov S.V. Russia's Agro Industrial Complex: Economic and Political Influence Factors and State Support. In: Solovev D. (eds) Smart Technologies and Innovations in Design for Control of Technological Processes and Objects: Economy and Production. FarEastCon 2018. Smart Innovation, Systems and Technologies, vol 138, 2020, pp 579-593.

[7] Chevassus-au-Louis B., Salles J.-M., Bielsa S., Richard D., Martin G. and Pujol J.-L. Approche économique de la biodiversité et des services liés aux ecosystems: contribution à la décision publique. Paris, Rapport du CAS, 2009.

[8] Dahiya A. Bioenergy: Biomass to Biofuels. NY: Associated Press, 2014.

[9] Shibu J. and Thallada B. Biomass and Biofuels: Advanced Biorefineries for Sustainable Production and Distribution. London: CRC Press, 2015.

[10] Hill J., Nelson E., Tilman D., Polasky S. and Tiffany D. Environmental, economic, and energetic costs and benefits of biodiesel and ethanol biofuels. Proceedings of the National Academy of Sciences, vol. 103(30), 2006, pp. 11206-11210.

[11] Northrop R.B., Connor A.N. Ecological Sustainability: Understanding Complex Issues. London: CRC Press, 2016. 548 p. 
[12] Tambovceva T., Tereshina M. and Samarina V. Green innovations in the regional economy.18th International Scientific Conference «Engineering for Rural Development». 22.-24.05.2019 Jelgava, LATVIA Proceedings, vol. 18, 2019, 1832-1839.

[13] Samarina V.P. Spatial and Temporal Variability of Biogenic Substances in the Oskol River Water. Water Resources, vol. 35 (3), 2008, pp. 346-352.

[14]Fargione J., Hill J., Tilman D., Polasky S. and Hawthorne P. Land clearing and the biofuel carbon debt. Science, vol. 319 (5867), 2008, pp. 1235-1238.

[15] Reay D.S. Not so sweet after all? Nature Climate Change, vol. 1, 2011, pp. 174-179.

[16] Sims R. Renewable energy: A response to climate change. Solar Energy, vol. 76, 2004, pp. 9-17.

[17]Foley J.A., Ramankutty N., Brauman K.A., Cassidy E.S. and Gerber J.S. Solutions for a cultivated planet. Nature, vol. 478 (7369), 2011, pp. 337-342.

[18] World Energy Congress - 2019 [online] [06.12.2019]. Available at: https://www.worldenergy.org/experiences-events/world-energy-congress

[19] Amer A., Nasim F.ul-H., Batool K. and Bibi A. Microbial $\beta$-Glucosidase: Sources, Production and Applications. Journal of Applied \& Environmental Microbiology, vol. 5(1), 2017, pp. 31-46.

[20] Pittman J.K., Dean A.P. and Osundeko O. The potential of sustainable algal biofuel production using wastewater resources. Bioresource Technology, vol. 102, 2011, pp. 17-25.

[21] Kumar S. and Sani R.K. Biorefining of Biomass to Biofuels: Opportunities and Perception. Springer International Publishing AG, 2018.

[22] Dahiya A. Bioenergy: Biomass to Biofuels and Waste to Energy. NY: Associated Press, 2020. $682 \mathrm{p}$.

[23] Treichel H. and Fongaro G. Improving Biogas Production: Technological Challenges, Alternative Sources, Future Developments. Springer International Publishing AG, 2019. 